\title{
Pathways To Islamic Education Renewal In Aceh (A Case Study of Dayah Ma'had al Ulum Diniyyah Mesjid Raya Samalanga)
}

\author{
Hasan Asari ${ }^{1}$, Abd. Mukti ${ }^{2}$, Syadidul Kahar ${ }^{3}$ \\ 1,2,3 Universitas Islam Negeri Sumatra Utara \\ (North Sumatra State University) \\ 1hasanasari_nst@yahoo.com \\ 2abdmukti@yahoo.com \\ 3syadidulk@yahoo.com
}

\section{Article History: Abstract:}

Submitted:

23-10-2020

This research examines the renewal initiative at Dayah Ma'had al Ulum Diniyyah Mesjid Raya Samalanga Islamic School. This study focuses on the renewal initiative

Accepted:

23-11-2020 during the leadership of Abon Abdul Aziz and Abu Hasanoel Bashri. This research is qualitative research with a historical approach. This research indicates that the Al Aziziyah Samalanga Islamic Education Foundation's modernization began during the leadership of Abon Abdul Aziz in 1958 and culminated in Abu Hasanoel Bashry in 1989. Social factors had been the most dominant factors of modernization of Islamic education in the foundation, including the birth of Islamic and public universities in Aceh, the adoption of information and communication technology (ICT), the requirement of diplomas for teachers and education personnel, and the involvement of alumni in the foundation.

Keywords: Dayah; Renewal; Modernization; Islamic Education; Aceh. 


\section{Introduction}

The rich history of Islamic education development in Indonesia provides tremendous resources for researchers and practitioners to learn about the dynamics of Islamic education developments that can be beneficial for contemporary educational practices. ${ }^{1}$ This research examines Islamic education in Aceh by using a historical approach to understand the institution's dynamics. This research covers the discussion of traditional dayah (Islamic boarding school), integrated dayah (Islamic boarding school), dayah tahfiz, or Islamic boarding school for Quranic memorization². Dayah, also known as

1 Mizaj Mizaj, “Dayah Darussalam Network and Dayah Awakening in Aceh," Budapest International Research and Critics Institute (BIRCI-Journal): Humanities and Social Sciences 1, no. 3 (2018): 13 22.

2 Benyamin Situmorang, "Model of Education Quality Management of Traditional Islamic Boarding Schools in Aceh," in 3rd Annual International Seminar on Transformative Education and Educational Leadership (AISTEEL 2018) (Atlantis Press, 2018). pesantren (Islamic boarding school), is one of the oldest Islamic educational institutions in Aceh. ${ }^{3}$ Although the traditional Islamic boarding schools still adhere to the Aceh tradition, most Islamic boarding school systems in Aceh are undergoing reforms. ${ }^{4} 5$ One such Islamic boarding school is Dayah Ma'had al Ulum Diniyyah Mesjid Raya (Mudi Mesra) Samalanga. The growth and development of Mudi Mesra Samalanga Dayah in its early days, the management of this Islamic boarding school, was handed over to Faqeh Abdul Ghani, a religious scholar of the Sultan. In this period, there were no other records regarding the condition and development of the Islamic boarding school under the leadership of Faqeh Abdul Ghani. Another note that mentions this Islamic

3 Charlene Hwee Phio Tan, "Educative Tradition and Islamic Schools in Indonesia," 2014.

4 Eka Srimulyani, "Islamic Schooling in Aceh: Change, Reform, and Local Context," Studia Islamika 20, no. 3 (2013): 467-87.

5 Sri Suyanta, "Idealitas Kemandirian Dayah," Jurnal Ilmiah Islam Futura 11, no. 2 (2012): 16-37. 
boarding school was only found in the history of another scholar known as Tgk. Syihabuddin bin Idris dated back to 1927. According to this history, around the 19th century, a dayah educational institution was formed by the ulama and Ulee Balang, namely Muhammad Ali Basyah, with a mutual agreement with the local community to appoint Tgk. Syihabuddin bin Idris as its leader6.

Based on the notes described in the official website of MUDI MESRA, an Islamic boarding school during the leadership of Tgk. Syihabuddin

has accommodated approximately 100 male students and more than 50 female students who came from various regions of Aceh for trading. After passing Tgk H. Syihabuddin in 1935, the Islamic boarding school management was then handed over to his brother-inlaw, Tgk. H. Hanafiah bin Ibn Abbas. During this period the number of students has also

${ }^{6}$ Tgk. Anwar Kuta Krueng and Mahfudhan Zulkifli, Dayah Dan Rabithah Thaliban Dalam Catatan Aceh (Dayah and Rabithah Thaliban in Aceh Records) (Banda Aceh: Rabithah Thaliban Aceh, 2010). increased to about 150 people with the same facility conditions. Tgk. H. Hanafiah bin Ibn Abbas then left for Mecca, and the Islamic boarding school's management was handed over to Tgk. M. Saleh (the parent of Abon Abdul Aziz), after two years of leadership, the administration was then handed over to Tgk. H. Ibrahim Lueng Keubeu until the return of Tgk. $\mathrm{H}$. Hanafiah bin Ibn Abbas from Mecca 7 . The learning system, facilities, and infrastructure during the Tgk. Syihabuddin and Tgk. Hanafiah was still very traditional and far from the modern style. At the time of Tgk. Hanafiah, there were already several teachers who helped in the learning process, although they remained using the traditional curriculum by teaching the yellow book (an Arabic textbook).

The death of Tgk. Hanafiah in 1958 then obliged one of his sons-in-law, Tgk.

7 Hasbi Amiruddin, "Biografi Ulama-Ulama Aceh Abad XX (Biography of XX Century Aceh Ulama)" (Banda Aceh: Dinas Pendidikan Provinsi Nanggroe Aceh Darussalam, 2003). 
H. Abdul Aziz bin Tgk. M. Shaleh, who is often called Abon Aziz, to take the leadership of dayah. For 31 years (1958 1989) Abon Aziz led dayah Mudi Mesra and it was in Abon Aziz's hands that the Dayah Mudi Mesra curriculum began to change. During his leadership, dayah reforms began after his return from studying at Dayah Darussalam Labuhan Haji. Abon Aziz was a student of Abuya Muda Wali AlKhalidy, a great scholar in Aceh at that time who led Dayah Bustanul Muhaqqiqien Darussalam Labuhan Haji, South Aceh. 8

On the other hand, students who participated in the trade grew to hundreds, including some Sumatra students. The management then replaced the boarding facility from bamboo and thatch roofs into a two-story semi-permanent dormitory building and a three-story permanent building to accommodate new students.

8 Waly Muhibbudin, Ayah Kami Maulana Syeikh Haji Muhammad Waly Al Khalidy:Teungku Syeikh Haji Muda Waly (Our Father Maulana Syeikh Haji Muhammad Waly Al Khalidy: Teungku Syeikh Haji Muda Waly) (Banda Aceh: Al Waliyah Publishing, 2016).
In addition to teaching students, Abon Aziz also hosted a public Islamic sermon every Thursday called balee hameh. ${ }^{9}$ In 1989, Tgk. H. Abdul Aziz passed away; his son-in-law, Tgk. H. Hasanoel Basri bin $\mathrm{H}$. Gadeng, then held the management. He is one of the most senior students and is involved in being the board of the Dayah with Abon Tgk. H. Abdul Aziz. ${ }^{10}$ The name of Tgk. H. Hasanoel Basri H.G. known as Abu Mudi was more popular not only by the dayah circles but also by the Acehnese community.

Under the leadership of Abu Mudi, dayah Mudi Mesra underwent a rapid modernization process, from the aspects of institutional management, educational models, curricula, to facilities that support all changes. Although Abu Mudi's thought drew a lot of criticism from the Islamic boarding school themselves. 11 YPIA Samalanga then no

9 Tim Penulis, "Profil Ringkas Dayah Mudi Samalanga (Brief Profile of Dayah Mudi Samalanga)," 2018.

10 Penulis.

11 Ismail Fahmi Arrauf Nasution, Miswari Miswari, and 
longer only runs education in the form of dayah salafiah, but tries to touch the lowest level of education to higher education starting by opening Al Quran Education Park, Kindergarten, Muadalah Wustha and Ulya Education Unit, Ma'had Aly, college high level of Islam as well as various Lajnah (Sub-agency) assistants. The number of students who came to Mudi Mesra was increasing both from Aceh and from outside Aceh. The increasing number of new students each year is also comparable to the progress of dayah alumni who helped develop Mudi Mesra by establishing a number of other dayahs throughout Aceh as branches of Mudi Mesra. Currently, the number of dayah branches under Mudi Mesra has reached 594 institutions. ${ }^{12}$ The number of graduates from this dayah also helps to develop various kinds of

Sabaruddin Sabaruddin, "Preserving Identity through Modernity: Dayah Al-Aziziyah and Its Negotiations with Modernity in Aceh," Hayula: Indonesian Journal of Multidisciplinary Islamic Studies 3, no. 2 (2019): 211-32.

12 Penulis, "Profil Ringkas Dayah Mudi Samalanga (Brief Profile of Dayah Mudi Samalanga)." educational programs. This research examines the background of the renewal of Islamic education in Dayah Mudi Mesra Samalanga.

\section{Method}

This study employed a qualitative research method ${ }^{13}$ through a historical approach. ${ }^{14}$ The purpose of using this approach is to find the dynamics of dayah Mudi Mesra Samalanga in terms of its developments. The data collection techniques used an active participatory observation, semi-structured interviews with dayah leaders, the teungku (senior key officials), students of Mudi Mesra Samalanga. This study also incorporated secondary documents such as administrative documents, pesantren guidelines, articles of foundation, schedule of activities, and other documents related to the renewal of Islamic education at Dayah Mudi Mesra

13 Joseph A Maxwell, "Designing a Qualitative Study," The SAGE Handbook of Applied Social Research Methods 2 (2008): 214-53.

14 Gordana Jovanović, "Toward a Social History of Qualitative Research," History of the Human Sciences 24, no. 2 (2011): 1-27. 
Samalanga ${ }^{15}$. This study's data analysis is employed by unitizing, categorizing, and interpreting the data.

\section{Result}

\section{Key developments of Dayah}

\section{Mudi Mesra Samalanga}

The birth of Islamic and

\section{Public Universities in Aceh}

The Islamic higher education in Aceh was founded as early as 1964, IAIN

Malikusshaleh

Lhokseumawe, as the development

Malikusshaleh

Religious College (STAI). Malikusshaleh University Lhokseumawe and $\mathrm{Al}$ Muslim Bireun University were founded in 1929.

These colleges in Lhokseumawe and Bireun are separate triggers for dayah students to continue their education. The establishment of UIN Arraniry and UNSYAH in Banda Aceh motivate students to continue their education at the university level.

15 Glenn A Bowen, "Document Analysis as a Qualitative Research Method," Qualitative Research Journal 9, no. 2 (2009): 27.
Some Mudi Mesra senior students continued their higher education both IAIN Malikussaleh, UIN Ar Raniry, Malikussaleh University. Based on the socio-economic status, the intention to study at the public institutions. Such a situation influenced $\mathrm{Abu}$ to establish a college in Dayah Mudi Mesra Samalanga so that senior students can study at the $\mathrm{Al}$ Aziziyah Foundation while becoming teachers or mentor at the boarding school.

Abu Hasanoel Bashry's motivation in modernizing was not just imagining imaginations without consideration; it was accompanied by planning and scientific considerations. This can be seen before he founded a college, he communicated with alumni, with IAIN Malikusshaleh Lhokseumawe, with Prof. M. Hasballah Thaib, MA. Ph.D. (Professor of Darma Wangsa University). He also conveyed to Jakarta to meet Farhan Hamid, who served as deputy chairman of the MPR RI. 


\section{Economic Factor}

The economic aspect has been one of the essential goals of human being. The economic development in Aceh, however, had changed the landscape of Islamic boarding house development 16. Before the establishment of companies in Aceh, parents preferred to send their children to Dayah or boarding school. The situation had changed when the natural gas source was discovered in Padang Arun in 1971. This development was followed by PT Arun NGL (1974-1978), PT ASEAN Aceh Fertilizer (AAF) (1981), PT Pupuk Iskandar Muda (PIM) 1984. With large companies, there are many job opportunities, an increase in the amount of money in circulation, an increase in the needs of daily life, and an increase in the demand for services, increasing business opportunities. With workers from outside Aceh, the

16 Dayan Dawood, Perubahan Sosial Budaya Dan Kemasyarakatan Akibat Pembangunan Industri-Industri Besar Di Aceh Utara (Social Change Due to Industrial Development in North Aceh) (Pusat Latihan Penelitian Ilmu-Ilmu Sosial, Aceh, Universitas Syiah Kuala, 1986).
Acehnese gained a lot of experience, so many North Acehnese who originally worked as fishers switched to starting new jobs such as bricks, wood factories, contractors, opening workshops, and becoming drivers. Many of the Acehnese at that time did not go to school, they entered the Islamic boarding school; instead, so many of them could not work in companies.

Based on the social and economic conditions of the community, the people of Aceh were very enthusiastic about sending their children to public schools. Based on these conditions, the Islamic boarding school finally carried out reforms so that the community would want to enroll their children in the dayah ${ }^{17}$. Some dayahs made changes by changing their status to modern dayahs or better known as modern pesantren. This also happened at Mudi Mesra Samalanga dayah. The dayah

17 Azhari Azhari, Cut Zahri Harun, and Khairuddin Khairuddin, "The Education Funding Management of Dayah Khairuddaraini Kabupaten Pidie," Proceedings of AICS-Social Sciences 9 (2019): 55-62. 
made renewal by opening itself up to change. Among them are providing opportunities for alumni to continue to higher education, opening package learning programs, and establishing higher education institutions in the MUDI dayah. The breakthrough that was carried out at the MUDI dayah was especially so that dayah alumni had a diploma and could be used to play a role in both government and private institutions.

\section{Information and}

\section{Communication Technology} (ICT)

Dayah Mudi Mesra Samalanga has responded to the increasing use of ICT (information and communication technology) to develop education. On the other hand, ICT poses internal challenges at the foundation, such as a lack of facility and students' negative exposure to internet technologies. Apart from the pros and cons of the impact of ICT, the foundation has adopted ICT in developing space for da'wa and education through the establishment of the Mudi missionary development institute (LPDM). The Center for Development of Da'wah Mudi (LPDM) is an institution in charge of the da'wa and publication section under the LPI MUDI Mesjid Raya Samalanga that has been inaugurated since November 2013. The center distributes Islamic teaching through the short video and radio. Tgk Ahmad Yani, a permanent lecturer at the $\mathrm{Al}$ Azizizyah Islamic Institute (IAIA) Samalanga, works as the editor of various videos of dayah activities and distributed to the public.

\section{Language Development}

Modern Islamic boarding schools, or in Aceh known as integrated Islamic boarding schools, are dayahs that manage education by incorporating general education. The characteristic of this dayah is developing both Arabic and English. According to Abu Hasanoel Bashry, the language mastery is an important thing to open the students' horizons. Following the Prophet Muhammad's teaching, learning languages could facilitate the Islamic teachingdevelopment in many areas. Likewise, Abu 
Mudi Foundation recognizes the important of learning languages. In general, every boarding school student must master both English and Arabic. However, the tradition of reciting the yellow book is not comparable to the level of mastery over Arabic itself, where most students only master Arabic passively. Meanwhile, most of the students also do not master the national language well because the language of instruction in the dayah is generally used in Acehnese. In the surah of the Arabic Jawi script, it is mixed with classical Malay.

Language skills have been a concern of Abu Mudi from the beginning of the foundation establishment. The foundation aimed at developing a foreign language program in addition to teaching national languages. The first step was to produce a cadre of foreign language teachers by sending outstanding students and teachers to the language course $^{18}$. In 2003, to accelerate

18 Zubaili Zubaili, "The Policy of Aceh Goverment in Developing the Dayah Teachers' Competence at the students' foreign language skills, Abu Mudi built a special dormitory for Arabic and English teachers. Then, Mabna Lughah was formed, supported by modern language laboratory facilities. With the formation of Mabna Lughah, foreign languages in Mudi Mesra continued to develop, where Arabic and English were widely spoken as the colloquial language of Mabna Lughah members and also used in i'lan (announcement). In 2005, foreign languages, mostly Arabic, began to be used as instruction in the female students' dormitory. Furthermore, in 2008, foreign languages' use was increasingly expansive, primarily Arabic for all Mudi Mesra environments, while English did not show encouraging results. In 2013, Mabna Lughah changed the Arabic and English learning system from being separate to a bilingual class by combining the two in each learning session.

Aceh-Post Tsunami," International Journal on Language, Research and Education Studies 1, no. 1 (2017): 117. 
The primary purpose of using language in the dayah as envisioned by Abu Hasanoel Basry is to motivate students to participate in various international activities. With the language program, MUDI dayah also received visits from national and international organizations. As previously explained, this change's purpose was not to compete with a traditional Islamic boarding house but to adapt to the growing global demand.

\section{Contribution from the Alumni}

The

Al Aziziyah Samalanga Islamic Education Foundation is one of the oldest educational institutions in Aceh which has produced thousands of alumni who have taken part in various institutions both nationally and internationally. This foundation also has 594 branches until 2018, so that alumni from YPIA apart from being born from YPIA are also born from dayah branches. In this case, dayahs are often seen as as more than educational institutions but also social movement. ${ }^{19} \mathrm{Abu}$ Hasanoel Bashry also noticed that in line with the increase in the number of new students each year, the number of Mudi Mesra alumni also increased. As is common in pesantren, the relationship between the dayah, santri and teungku in Aceh is also more familial so that even though they no longer study at the dayah, these alumni see themselves as students and the relationship between the three remains good. Mudi Mesra alumni have spread throughout Aceh and many regions in Indonesia. Some have established dayahs in their respective areas of origin, some work in government and private agencies, and some continue their education elsewhere. To strengthen the alumni network at Mudi Mesra, the MUDI Mesjid Raya Samalanga Alumni Rabithah was established in 1989 but its function was still limited to associations. Abu Mudi then developed this organization

19 Hanafiah Hanafiah, "Dayah Collectively as a Social Movement," International Journal of Human Rights in Healthcare, 2018. 
as one of the sub-units under the Al-Aziziyah Islamic Education Foundation which can help develop various educational programs from Mudi Mesra.

Abu Mudi fostered alumni intensively through the Alumni Rabithah so that a productive alumni network developed to help support fatherhood programs, especially by establishing dayah branches in their areas of origin and being fostered by Mudi Mesra. Until 2018, the number of dayah branches under Mudi Mesra has reached 594 educational institutions. Rabithah Alumni LPI MUDI Mesjid Raya is an organization that houses MUDI dayah alumni under the Al Aziziyah foundation which unites all alumni since the leadership of Abi Hanafiah, Abon Aziz and now Abu MUDI. The MUDI Alumni Rabitah was formed and inaugurated right after the death of Abon Aziz. The Chairman of the Alumni Association for the first time after being inaugurated was the late. Abu Qasem TB as one of the oldest MUDI dayah alumni at that time. Then also formed Alumni Associations per district/city throughout the province of Aceh and outside Aceh. Until now, Rabithah Alumni have routinely held Haul Abon celebrations every year in their respective places, and on a large scale every two years at the main dayah, Mudi Mesra. Rabithah Alumni of LPI MUDI Mesjid Raya intently conducts alumnibuilding activities. The relationship between the main dayah, namely YPIA and the alumni's dayah, is effectively established both from the vision and mission or others. Dayah MUDI has produced many alumni, some of whom have continued their studies at home and abroad. Some have worked in government agencies, are selfemployed, and mostly teach majelis ta'lim and established dayahs in their respective areas. On the other hand, with this alumni association, a new change will be built with alumni's various ideas after working in different institutions both at home and abroad. 
Key Figures of the Islamic Education Renewal of Dayah Mudi Mesra Samalanga

Prominence figures hold an important position in dayah or Islamic boarding school $^{20}$. Key figures in dayah lead and manage key activities in dayah along with their support staff and teachers. The renewal of Dayah Mudi Mesra Samalanga could not be separated from key figures' personal and intellectual factors in the dayah. Two prominent figures influence the development of dayah Mudi Mesra Samalanga, Abon Abdul Aziz and Abu Hasanoel Bashry.

\section{Abon Abdul Azis}

During the leadership of Abon Abdul Aziz, dayah Mudi Mesra has experienced changes from various aspects. This can be seen from the intellectual background of Abon Abdul Aziz. In 1948, Abon continued his education at a dayah led by Teungku

20 Mukhlisuddin Ilyas and Abdul Muin Sibuea, "Leadership Transformation; Study of Islamic Boarding School (Dayah) in Aceh Province of Indonesia," Journal of Entrepreneurship Education 22, no. 2 (2019): 1-5.
Ben (Teungku Tanjongan) in Matangkuli, North Aceh Regency. In this dayah, Abon studied at Teungku Idris Tanjongan until 1949. At the same time, he returned to MUDI Dayah Mesjid Raya Samalanga to devote himself as a teacher. After he served as a teacher for several years, in 1951, Abon continued his study at Dayah Darussalam Labuhan Haji South Aceh, which was led by Syeikh Muhammad Waly Al-Khalidi or better known as Abuya Muda Wali. Abon studied in Dayah Darussalam for about seven years. The late Tgk. Muhammad

Amin

Tanjongan, an Abon student who also studied at Labuhan Haji, once told that when he was repeating a lesson (muthala'ah), Abon opened all the books related to the lesson being learned so that his room was seen scattered with books. Starting from 1958, Abon Abdul Aziz has begun to play his role to organize the education system in Mudi Mesra dayah to produce to a qualified generation to serve amid society. Since Dayah MUDI Mesjid Raya was under his leadership, many changes have occurred, especially 
regarding the educational curriculum. Abon emphasizes the students to be able to understand the science of tools in detail so that the analysis of the turats content can be sharpened. Abon wanted students to understand the express content and the implied content that could only be understood by mastering the knowledge of tools so that they were able to uncover the signs contained in the Arabic text. It can be seen here that Abon Abdul Aziz emphasizes understanding the tools of science for his students, and he is a student of Abuya Muda Waly who was given the title by Abuya as Al Mantiqi.

Abon is deeply steeped in the science of mantiq which is the science of mizan (science of weighing) to judge whether a thought is real or not. The qualified knowledge in this mantiq fan also makes the evidence (arguments) that Abon provides is very strong and difficult to refute. Based on the educational journey provided by Abon Abdul Aziz, it had an impact on the changes in Mudi Mesra Samalanga's dayah. The development of education carried out at the Mudi Mesra dayah followed the concept of education in the Darussalam Labuhan Haji South Aceh dayah. Both in the field of facilities and infrastructure, the education system uses the madrasah system; in this system students already use a bench and a blackboard and do not emphasize the text of the book, but there should be a lot of discussion for deepening. Education at Dayah Mudi Mesra issues certificates for students who have completed education, such as in Dayah Darussalam Labuhan Haji South Aceh.

The modernization carried out by Abon Abdul Aziz is in the field of curriculum, he places great emphasis on the science of tools and other books. According to him, the science of tools not only understands the book's surah explicitly but implicitly. The existence of the observers of the book cannot answer the problems of the people if it is understood explicitly, with the knowledge of tools, the eyes of the book are able to explain the content of the law with the actual problem. 
Abu Hasanoel Bashry

Haji Hasanoel Bashry Haji Gadeng, familiarly called Abu MUDI, is a highcharismatic Acehnese scholar. He is known to be very pious in fiqh, the proposal of fiqh, and several other disciplines. Due to his breadth of knowledge, he has become a highly respected and admired figure in Aceh. In 1956, Abu MUDI started his formal education at the Krueng Geukueh Islamic Low School (SRI), Dewantara District, and North Aceh. As a rule, Abu MUDI completed his education at SRI in 1962. In 1962, Abu MUDI continued his formal education at a teacher education institution, the First Religious Teacher Education (PGAP) Krueng Geukueh. Then, he finished his formal education and continued his education at the Dayah Ma'hadal Ulum Diniyyah Islamiyyah (MUDI) Islamic Education Institute (MUDI) Mesjid Raya.

Abu MUDI studied with many senior religious figures, including The late $\mathrm{Abu}$ Ibrahim Bardan (Abu Panton), Panton Labu, Abu Ishak (Abu Langkawe), Pidie, Tgk. Haji Daud Abbas (Tgk Lhok), Tgk. Abdul Ghani,
Abu Abdul Mannan East Aceh, and other teachers. Abu MUDI also received special education from his private teachers, among his private teachers was Abu Daud Abbas, a figure who was also a teacher at the MUDI dayah Mesjid Raya Samalanga who came from South Hagu, Lhokseumawe City. Abu Daud paid great attention and was very serious in guiding Abu MUDI. He emphasized Abu MUDI about the importance of memorizing books and repeating them all the time. Under the guidance and direction of Abu Daud, Abu MUDI managed to memorize many books. In fact, he had been locked up in a room for days to study.

Based on Abu Hasanoel Basri's intellectual background, it can be seen that he received formal education, namely SRI and PGAP, and non-formal education, namely Dayah Mudi Mesra Samalanga. This has contributed to the rapid changes in Dayah Mudi Mesra Samalanga and is now under the auspices of the $\mathrm{Al}$ Aziziyah Samalanga Islamic Education Foundation. The most important of these influences is accepting change 
and making changes so that Dayah Mudi Mesra continues to stand firm with the changing times. Based on that spirit, where da'wa must be developed widely. Many Mudi graduates have also been able to take part in the formal sector because Mudi Mesra alumni have obtained diplomas. Therefore, Abu founded the Al-Aziziyah Islamic Institute (IAI). There is no doubt that the Samalanga Islamic Education Foundation is the most successful dayah today in terms of management development, development, and growth in the number of students. In terms of the development, during the Abon era only wooden dormitories and dormitories were established. Now permanent dormitories from 3 to 5 floors have been established, and the development of the sudents proves the increasing trust that society put to the foundation.

Based on social intellectuals, the changes made by Abu Hasanoel cannot be separated from the development of education in Aceh. Likewise, the changes made by Abon Abdul Aziz, following the concept of education obtained from Dayah Darussalam Labuhan Haji, led by Abuya Muda Waly Al Khalidi. The difference between the changes made by the two Dayah Mudi Mesra (YPIA) leaders was Abon Abdul Aziz, curriculum and management modifications followed by dayah changes based on Dayah Darussalam. On the other hand, Abu Hasanoel Bashri was based on the social intellectual development that occurred in Aceh, which was obtained from MUDI dayah and education. Basically, Abon strongly forbids Dayah Mudi Mesra students from continuing to Islamic tertiary education. According to him, Islamic universities have hardliner influence from Wahabi. However, such influence, did not happen during Abu Hasanoel Bashri; although he established an Islamic university.

\section{Conclusion}

Based on the findings in this study, it can be concluded that the occurrence of modernization at the $\mathrm{Al}$ Aziziyah Samalanga Islamic Education Foundation began 
in Abon Abdul Aziz's leadership starting in 1958 and emerged in the administration of $\mathrm{Abu}$ Hasanoel Bashry, in 1989. Social factors are the most dominant factor in the modernization of Islamic education at the Samalanga Islamic Education Foundation, including the birth of Islamic and public universities in Aceh, economics, information and communication technology (ICT), language development, and the contribution from the alumni.

\section{References}

Amiruddin, Hasbi. "Biografi Ulama-Ulama Aceh Abad XX (Biography of XX Century Aceh Ulama)." Banda Aceh: Dinas Pendidikan Provinsi Nanggroe Aceh Darussalam, 2003.

Azhari, Azhari, Cut Zahri Harun, and Khairuddin Khairuddin. "The Education Funding Management of Dayah Khairuddaraini

Kabupaten Pidie."

Proceedings of AICS-Social

Sciences 9 (2019): 55-62.

Bowen, Glenn A. “Document
Analysis as a Qualitative Research Method." Qualitative Research Journal 9, no. 2 (2009): 27. Dawood, Dayan. Perubahan Sosial Budaya Dan Kemasyarakatan Akibat Pembangunan IndustriIndustri Besar Di Aceh Utara (Social Change Due to Industrial Development in North Aceh). Pusat Latihan Penelitian IlmuIlmu Sosial, Aceh, Universitas Syiah Kuala, 1986.

Hanafiah, Hanafiah. "Dayah Collectively as a Social Movement." International Journal of Human Rights in Healthcare, 2018.

Ilyas, Mukhlisuddin, and Abdul Muin Sibuea. “Leadership

Transformation; Study of Islamic Boarding School (Dayah) in Aceh Province of Indonesia." Journal Entrepreneurship

Education 22, no. 2 (2019): 1-5.

Jovanović, Gordana. “Toward a Social History of Qualitative Research." History of the Human Sciences 24, no. 2 (2011): 1-27.

Krueng, Tgk. Anwar Kuta, 
and Mahfudhan Zulkifli. Dayah Dan Rabithah Thaliban Dalam Catatan Aceh (Dayah and Rabithah Thaliban in Aceh Records). Banda Aceh: Rabithah Thaliban Aceh, 2010.

Maxwell, Joseph A.

"Designing a Qualitative Study." The SAGE Handbook of Applied Social Research Methods 2 (2008): 214-53.

Mizaj, Mizaj. "Dayah Darussalam Network and Dayah Awakening in Aceh." Budapest International Research and Critics Institute (BIRCIJournal): Humanities and Social Sciences 1, no. 3 (2018): 13-22.

Muhibbudin, Waly. Ayah Kami Maulana Syeikh Haji Muhammad Waly Al Khalidy:Teungku Syeikh Haji Muda Waly (Our Father Maulana Syeikh Haji Muhammad Waly Al Khalidy: Teungku Syeikh Haji Muda Waly). Banda Aceh: Al Waliyah Publishing, 2016.

Nasution, Ismail Fahmi Arrauf, Miswari Miswari, and Sabaruddin Sabaruddin. "Preserving Identity through Modernity:
Dayah Al-Aziziyah and Its Negotiations with Modernity in Aceh." Hayula: Indonesian Journal of Multidisciplinary Islamic Studies 3, no. 2 (2019): 211-32.

Penulis, Tim. "Profil Ringkas Dayah Mudi Samalanga (Brief Profile of Dayah Mudi Samalanga)," 2018. Situmorang, Benyamin. "Model of Education Quality Management of Traditional Islamic Boarding Schools in Aceh." In 3rd Annual International Seminar on Transformative Education and Educational Leadership (AISTEEL 2018). Atlantis Press, 2018.

Srimulyani, Eka. "Islamic Schooling in Aceh: Change, Reform, and Local Context." Studia Islamika 20, no. 3 (2013): 467-87.

Suyanta, Sri. "Idealitas Kemandirian Dayah." Jurnal Ilmiah Islam Futura 11, no. 2 (2012): 16-37.

Tan, Charlene Hwee Phio. "Educative Tradition and Islamic Schools in Indonesia," 2014.

Zubaili, Zubaili. "The Policy of Aceh Goverment in Developing the Dayah 
Hasan Asari, at all.

Teachers' Competence at Aceh-Post Tsunami." International Journal on Language, Research and Education Studies 1, no. 1 (2017): 1-17.

240 | Nadwa: Jurnal Pendidikan Islam 